\title{
POTENCY OF EEL Anguilla marmorata in NORTH LOMBOK REGENCY, WEST NUSA TENGGARA PROVINCE
}

\author{
Bagus Dwi Hari Setyono $^{1}$ - Muhammad Junaidi ${ }^{1}$ · Muhammad \\ Marzuki $^{1} \cdot$ Paryono $^{1} \cdot$ Fariq Azhar $^{1}$
}

\begin{abstract}
Anguilla spp. is one of the fishery commodities that have high economic value. North Lombok regency is one of the central part of Indonesia which is suspected to have potential as an eel migration route. This study aims to obtain information about the identification of Anguilla spp fish populations. in North Lombok Regency. The results showed that the waters area of North Lombok Regency has the potential of eel fish source Anguilla marmorata. The timing of eel migration is still unknown, so further research is needed which will cover a full year.
\end{abstract}

Keywords Eel, Anguilla spp, North Lombok, Potency, West Nusa Tenggara

Received : 02 Desember 2017

Accepted : 07 Januari 2018

\section{PENDAHULUAN}

Ikan sidat merupakan salah satu komoditas perikanan yang memiliki nilai ekonomis tinggi. Permintaan ikan sidat di pasar internasional yaitu dari negaranegara di Asia, Eropa, Amerika, dan Australia yang mencapai Rp 250.000,00 ton/tahun (Ringuet et al., 2002). Harga ikan sidat di pasar internasional saat ini berkisar antara Rp180.000,00 sampai Rp300.000,00/kg (FAO, 2014). Harga

\footnotetext{
$\left.{ }^{1}\right)$ Program Vokasi (PDD) Universitas Mataram di Kabupaten Lombok Utara.

E-mail: bagus.unram@gmail.com
}

sidat pada pasar lokal untuk ukuran konsumsi berkisar antara Rp120.000,00 sampai Rp180.000,00/kg (KKP, 2011). Permintaan ikan sidat yang besar belum terpenuhi seluruhnya. Berdasarkan data KKP (2011), dari Rp130.000,00 ton/tahun permintaan pasar global hanya $16,8 \%$ yang bisa dipenuhi dari hasil tangkapan dan budidaya.

Tingginya permintaan pasar global terhadap ikan sidat dikarenakan ikan ini memiliki kandungan yang tinggi akan protein, lemak, vitamin A, B1, B2, C, D, dan E serta beberapa mineral lain dalam dagingnya (Rovara, 2007). Suitha and Suhaeri (2008) juga menyatakan bahwa kandungan EPA ikan sidat $1.337 \mathrm{mg} / 100 \mathrm{~g}$ mengalahkan ikan salmon yang hanya $820 \mathrm{mg} / 100$ $\mathrm{g}$ atau tenggiri $748 \mathrm{mg} / 100 \mathrm{~g}$. Kandungan DHA ikan sidat $742 \mathrm{mg} / 100 \mathrm{~g}$, lebih tinggi dari ikan salmon dan tenggiri yang hanya $492 \mathrm{mg} / 100 \mathrm{~g}$ dan $409 \mathrm{mg} / 100 \mathrm{~g}$.

Perairan Indonesia yang terdiri dari sungai dan laut memiliki potensi yang cukup besar bagi penyebaran ikan sidat. Kondisi ini sesuai dengan ikan sidat yang bersifat katadromus, yaitu ikan sidat dewasa akan melakukan migrasi ke laut untuk melakukan pemijahan, sedangkan larva ikan sidat hasil pemijahan akan kembali lagi ke perairan tawar. Pengembangan budidaya ikan sidat sudah dimulai sejak tahun 1894 hingga sekarang (Usui, 1974). Namun demikian, masih terdapat kendala dalam budidaya ikan sidat, antara lain ketersediaan benih yang bergantung pada pola migrasi di alam. Menurut Sugeha et al. (2008), pola migrasi ikan sidat mengalami perubahan. Hasil penelitiannya menunjukkan 
bahwa pola migrasi antara ikan sidat di bagian barat, tengah, dan timur tidaklah sama. Penelitian yang dilakukan secara serentak di tiga wilayah tersebut menemukan bahwa musim kemarau merupakan puncak kelimpahan sidat di Indonesia bagian tengah yaitu pada bulan April sampai Oktober. Adapun di wilayah Indonesia bagian barat dan timur pada musim kemarau kelimpahannya rendah.

Kabupaten Lombok Utara merupakan salah satu wilayah Indonesia bagian tengah yang memiliki potensi sidat. Berdasarkan kondisi wilayah, terdapat beberapa aliran sungai yang bermuara ke laut memungkinkan menjadi alur migrasi ikan sidat. Menurut informasi dari masyarakat, sidat atau yang biasa disebut sebagai ikan tune, dapat ditangkap dengan alat pancing di beberapa lokasi. Ukuran ikan sidat yang ditangkap bervariasi, ada yang mencapai lengan tangan orang dewasa. Berdasarkan informasi tersebut, maka perlu dilakukan studi tentang identifikasi jenis ikan sidat di Kabupaten Lombok Utara. Hal tersebut menjadi penting untuk mendukung usaha budidaya yang sangat bergantung pada stok benih di alam.

Penelitian ini bertujuan untuk memperoleh informasi tentang identifikasi jenis ikan sidat di Kabupaten Lombok Utara. Hasil penelitian ini diharapkan dapat menjadi informasi awal dalam rangka pengembangan sumberdaya ikan sidat di Kabupaten Lombok Utara.

\section{MATERI DAN METODE}

Penelitian ini dilaksanakan dengan metode survei, yaitu mengambil sampel ikan sidat pada lokasi yang diduga terdapat potensi sumberdaya ikan sidat. Pengumpulan data meliputi data primer dan data sekunder. Data primer meliputi lokasi penangkapan ikan sidat, identifikasi jenis ikan sidat yang tertangkap, dan waktu migrasi ikan sidat. Data sekunder dikumpulkan melalui studi pustaka mengenai keadaan umum lokasi penelitian dan berbagai aspek biologi ikan sidat. Data yang diperoleh dibahas secara deskriftiv. Identifikasi ikan sidat dilakukan dengan metode Elie (1982) dalam Fahmi (2010).

Penangkapan ikan sidat Anguilla spp. dilakukan pada tiga lokasi yang berbeda, yaitu Sungai
Table 1 Kisaran Ruas Tulang Anodorsal Ikan Sidat Anguilla spp. (Watanabe et al., 2005)

\begin{tabular}{ccc}
\hline Spesies & $\begin{array}{c}\text { Jumlah Ruas } \\
\text { Tulang Anodorsal }\end{array}$ & Morfometrik (\%) \\
\hline A. bicolor pacifica & $1-3$ & $<0,2$ \\
A. bicolor bicolor & $1-3$ & $0,2-0,8$ \\
A, marmorata & $14-18$ & $16-20$ \\
A. nebulosa nebulosa & $19-22$ & $>20$ \\
\hline
\end{tabular}

Sire, Sungai Kapu, dan Sungai Montongpaal (Gambar 1). Pemilihan lokasi penangkapan didasarkan pada informasi warga sekitar yang menyatakan bahwa pada lokasi tersebut diketahui terdapat potensi ikan sidat. Pengambilan data dilakukan sebanyak tiga kali, yaitu pada tangggal 25-27 Agustus, 24-26 September, dan 26 Oktober. Pemlihan waktu penangkapan tersebut didasarkan pada fase terjadinya bulan gelap dalam penanggalan kalender lunar. Hal tersebut sesuai dengan karakteristik ikan sidat yang melakukan migrasi pada musim penghujan saat bulan gelap tiba. Haraldstad et al. (1985) menyatakan bahwa ikan sidat tidak melakukan migrasi selama bulan purnama. Hal tersebut terkait dengan intensitas cahaya dan perilaku menghindari predator. Usui (1974) menguatkan hal tersebut bahwa ikan sidat tidak melakukan migrasi pada kawasan sungai di Eropa yang terkena paparan sinar cahaya dari mercusuar pantai meskipun fase bulan gelap sedang berlangsung.

Karakter kunci Anal Dorsal Vertebrata (ADV), yaitu perhitungan jumlah ruas tulang anodorsal (anodorsal vertebrae) merupakan salah satu metode dalam melakukan identifikasi ikan sidat (Ndobe, 2010). Hal tersebut karena setiap jenis (spesies) ikan sidat memiliki nilai ADV yang sfesifik. Ruas tulang anodorsal yang dihitung adalah ruas-ruas yang tepat berada di antara ujung sirip dorsal dan ujung sirip anal (Gambar 2). Apabila ada ruas tulang punggung yang simetris dengan ujung sirip dorsal atau ujung sirip anal atau kedua ujung sirip tersebut, maka ruas tersebut tadi tidak dihitung. Hubungan antara kisaran ruas tulang anodorsal ikan sidat Anguilla spp. dengan jenis spesiennya dapat dilihat pada Tabel 1 .

Elie (1982) dalam Fahmi (2010) menyatakan bahwa pengukuran morfometrik juga dapat digunakan sebagai penguatan data dalam menentukan jenis ikan sidat. Nilai morfometrik menggambarkan perbandingan antara selisih panjang dor- 

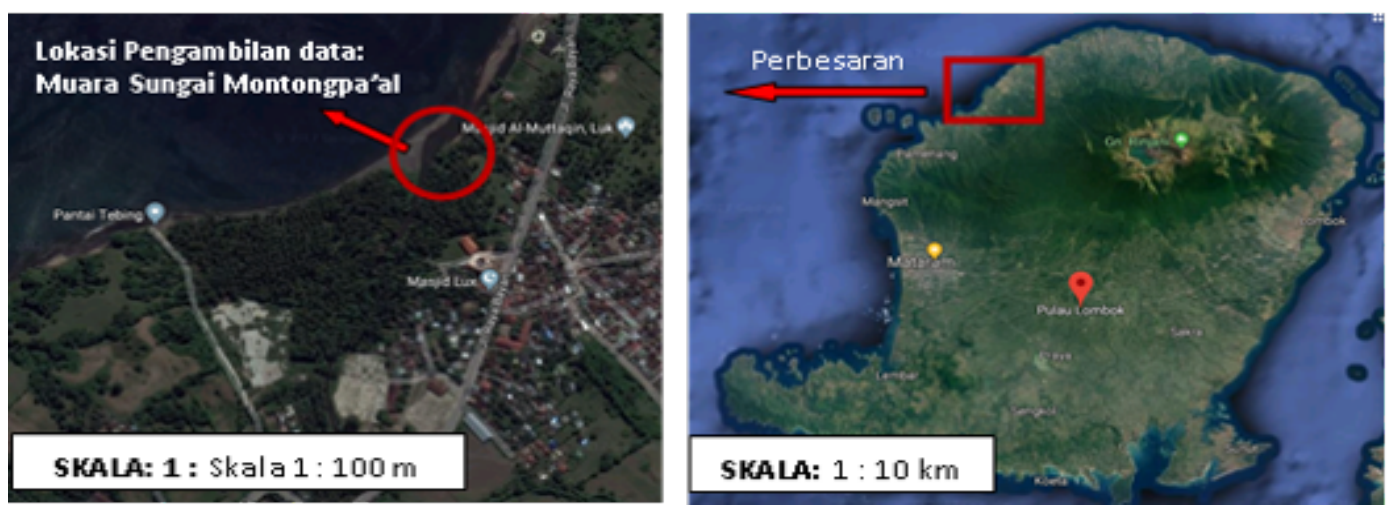

Figure 1 Muara Sungai Montongpaal, Kabupaten Lombok Utara

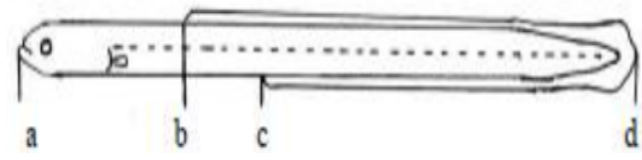

Keterangan: $a-d=$ panjang total $(T L) b-d=$ panjang dorsal (DL) $\mathrm{c}-\mathrm{d}=$ panjang anal $(\mathrm{AL}) \mathrm{b}-\mathrm{c}=$ Anodorsal

Figure 2 Karakter kunci perhitungan ADV

sal dan anal dengan panjang total yang dikalikan $100 \%$. Sama halnya dengan ADV, nilai morfometrik setiap ikan sidat juga memiliki sfesifikasi tersendiri, yaitu yang disajikan pada Tabel 1 (Tesch et al., 2003). Pengukuran nilai morfometrik dapat diketahui berdasarkan persamaan (1).

$A / D \%=\frac{D L-A L}{T L} \times 100 \%$

Penangkapan ikan sidat dilakukan dengan menggunakan dua jenis alat tangkap, yaitu bubu dan pancing. Desain bubu dapat dilihat pada Gambar 3. Kedua jenis alat tangkap tersebut dipilih berdasarkan pertimbangan keamanan faktor lingkungan, yaitu alat tangkap tidak bersifat menggangu keseimbangan ekosistem.

Bubu merupakan alat penangkap ikan yang ramah lingkungan. Prinsip kerja alat tangkap ini adalah menjebak ikan agar dapat memasuki ruang kosong pada bagian bubu. Agar ikan tertarik untuk masuk ke dalam ruangan bubu, maka pada bagian dalam bubu diberikan rumbai tali rafia yang telah dilapisi umpan yang berperan sebagai shelter dan atraktan. Jalur masuk menuju ruangan di dalam bubu didesain sedemikian rupa, yaitu berbentuk runcing, sehingga diharapkan ikan yang telah memasuki ruangan tersebut tidak dapat keluar lagi. Penggunaan bubu sebagai alat tangkap ikan, terutama ikan sidat, telah digunakan pada berbagai kawasan penghasil benih ikan sidat, antara lain di kawasan Teluk Poso Sulawesi Tengah.

\section{HASIL DAN PEMBAHASAN}

Hasil penangkapan benih ikan sidat disajikan pada Tabel 2. Hasil pengamatan pada Tabel 2 menunjukkan bahwa Kabupaten Lombok Utara memiliki potensi sumberdaya ikan sidat. Sungai Montongpal merupakan lokasi pengamatan dengan jumlah tangkapan ikan sidat terbanyak, yaitu 6 ekor yang terdiri dari 4 ekor berukuran fase elver ( 1-2 gram/ekor) dan 2 ekor sisanya berukuran fase yellow eel ( \pm 100 gram/ekor) (Gambar 4).

Tertangkapnya ikan sidat fase elver pada kawasan perairan Sungai Montongpal mengindikasikan bahwa kawasan perairan tersebut merupakan jalur migrasi ikan sidat. ? menyatakan bahwa ikan sidat yang sudah cukup dewasa dan siap untuk memijah, akan melakukan migrasi dari kawasan perairan yang lebih tinggi (hulu sungai) menuju ke kawasan perairan yang lebih rendah (muara sungai). Ikan sidat tersebut kemudian menetap untuk beberapa waktu pada kawasan muara untuk mempersiapkan migrasi selanjutnya, yaitu menuju ke perairan laut. Ikan sidat akan memijah pada kawasan laut dengan kedalaman sekitar 400 meter, kemudian saat memasuki fase glass eel atau elver, ikan sidat akan kembali melakukan migrasi menuju perairan tawar melalui muara sungai. 


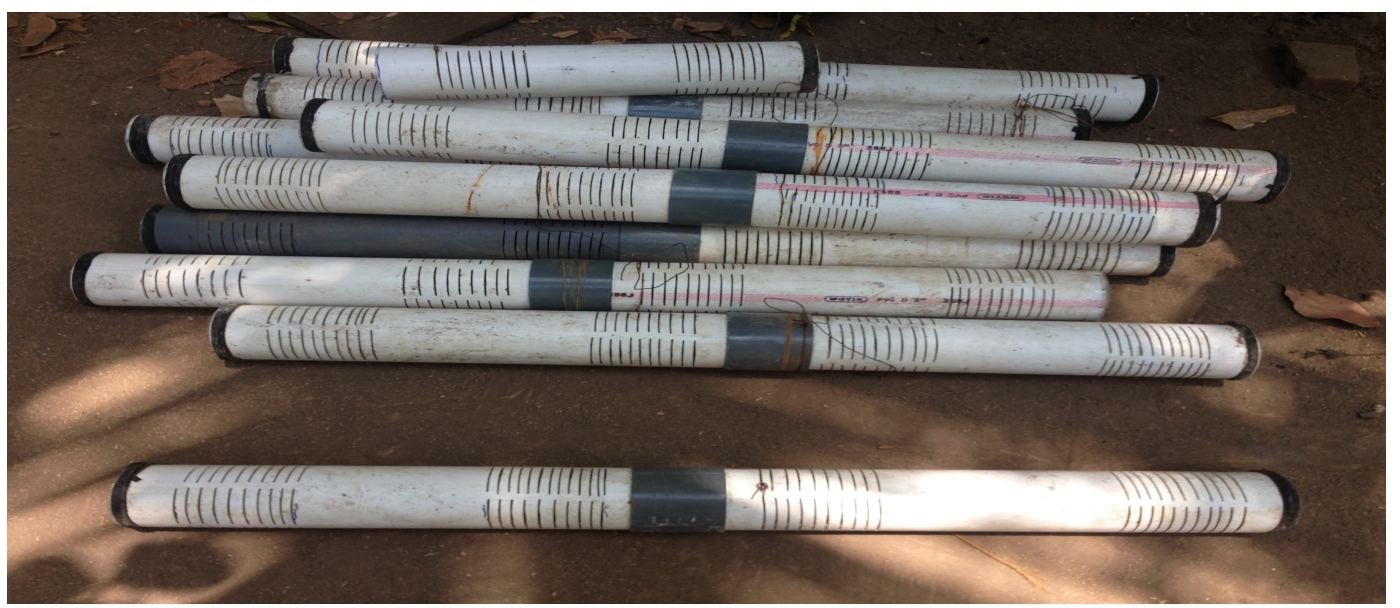

Figure 3 Alat tangkap ikan sidat (bubu)

Table 2 Hubungan panjang dan berat rata-rata serta pesebaran lokasi tangkap ikan sidat

\begin{tabular}{ccccc}
\hline No & Lokasi penangkapan & Jumlah (ekor) & Panjang $(\mathrm{cm})$ & Berat $(\mathrm{g})$ \\
\hline 1 & Sungai Kapu & 2 & $26-30$ & $42-47$ \\
2 & Sungai Montongpal & 6 & Sep-38 & $0,8-104$ \\
3 & Sungai Sire & 0 & - & - \\
\hline
\end{tabular}

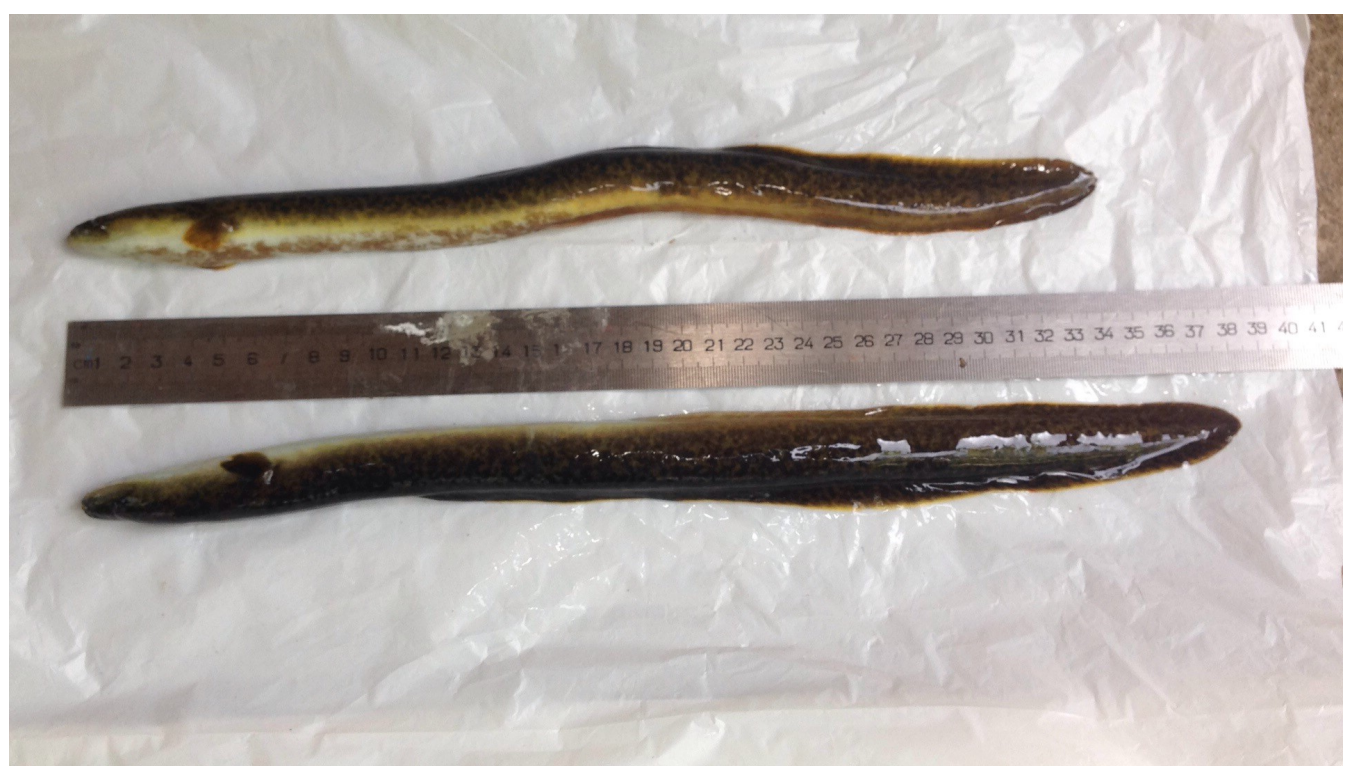

Figure 4 Ikan sidat yang tertangkap pada kawasan Sungai Montongpal

Ikan sidat memiliki karakterisitik sebagai hewan yang hidup secara berkelompok. Hal tersebut sesuai dengan hasil penelitian Harianto (2014) yang menunjukkan bahwa ikan sidat dapat tumbuh lebih baik pada suatu lingkungan dengan padat tebar yang lebih tinggi, hingga mencapai batas optimumnya. Ikan sidat yang tertangkap pada fase elver di kawasan Sungai Montongpal mengindikasikan bahwa masih adanya peluang terdapatnya benih-benih ikan sidat dengan jumlah yang lebih banyak yang dapat ditangkap. Desain alat tangkap yang ramah lingkungan menjadi suatu isu yang perlu diperhatikan agar pemanfaatan potensi sumberdaya ikan sidat dapat berjalan dengan optimal dengan tidak mengganggu kestabilan ekosistem. Oleh karena itu, penangkapan ikan sidat pada kawasan tersebut masih sangat perlu untuk dikaji lebih jauh dengan memperhatikan metode alat tangkap yang baik. 
Pergerakan migrasi ikan sidat dari perairan laut menuju perairan tawar terjadi pada kisaran waktu tertentu dalam siklus tahunan. Ndobe (2010) menyatakan bahwa pergerakan migrasi ikan sidat terjadi pada musim penghujan yaitu pada saat-saat memasuki bulan gelap. Matsui (1982) mendukung hal tersebut yaitu sesuai dengan pernyataannya bahwa pergerakan migrasi ikan sidat Anguilla japonica dapat terhenti pada kawasan sungai yang terkena paparan sinar oleh cahaya mercusuar. Hasil penelitian Haryono and Wahyudewantoro (2017) menguatkan hal tersebut, yaitu bahwa ikan sidat yang tertangkap pada musim penghujan berjumlah lebih banyak dibandingkan pada saat musim kemarau pada satu lokasi penangkapan yang sama. Berdasarkan hal tersebut, untuk mengetahui potensi ikan sidat pada kawasan Sungai Montongpal secara keseluruhan, maka diperlukan suatu kajian dalam rentang waktu yang mencakup dua musim (penghujan dan kemarau) yaitu minimal satu tahun.

Aoyama (2009) menyatakan bahwa sidat terdiri dari sekitar 18 jenis spesies yang tersebar di seluruh dunia. Berdasarkan Sugeha et al. (2008), dari seluruh jenis spesies tersebut, terdapat 9 jenis yang berada di kawasan peraian Indonesia. Kesembilan jenis tersebut antara lain: Anguilla bicolor bicolor, Anguilla bicolor pasifica, Anguilla marmorata, Anguilla nebulosa nebulosa, Anguilla borneensis, Anguilla interioris, Anguilla celebensis, obscura, dan Anguilla megastoma. Fahmi (2015), menyatakan bahwa ikan sidat tersebut tersebar pada kawasan sepanjang pantai Sumatra, pesisir selatan Jawa, Bali, NTB, NTT, sepanjang pantai timur Kalimantan, perairan Sulawesi (terutama Sulawesi Tengah), Maluku, dan Papua.

Keberadaan sumberdaya ikan sidat di Indonesia menjadi suatu landasan penting sehingga upaya pengembangannya dapat dikatakan layak untuk dilakukan. Sebagai bagian dalam upaya pengembangan, maka langkah awal yang dapat dilakukan adalah dengan melakukan pemetaan lokasi pesebaran serta jenis ikan sidat yang ada. Suatu kawasan lokasi yang terdapat jenis ikan sidat, terutama jenis yang paling diminati pasar, yaitu A. bicolor dan A. marmorata, maka kawasan tersebut berpotensi menjadi lokasi penangkapan sumber benih yang kemudian dipelihara dalam kegiatan akuakultur. Untuk mengetahui jenis ikan sidat hasil tangkapan di suatu kawasan lokasi, maka harus dilakukan suatu kegiatan identifikasi.

Berdasarkan hasil pengamatan identifikasi jenis ikan sidat yang disajikan pada Tabel 3, dapat diketahui bahwa ikan sidat tangkapan pada kawasan perairan sungai Kapu dan Montongpal diduga berjenis Anguilla marmorata. Ruas tulang anodorsal ikan sidat tersebut berjumlah 14 - 15 buah. Jumlah tersebut sesuai dengan pernyataan Watanabe et al. (2005), bahwa ikan sidat $A$. marmorata memiliki jumlah ruas tulang anodorsal berkisar $14-18$. Hasil perhitungan morfometrik sebesar 17-20\% juga mendukung hal tersebut, yaitu bahwa kisaran nilai morfometrik ikan sidat $A$. marmorata adalah $16-20 \%$ (Watanabe et al., 2005).

Fahmi (2010) dan Budiharjo (2010), menyatakan bahwa perairan selatan Pulau Jawa dan Sumatera yang berbatasan langsung dengan Samudra Hindia merupakan kawasan pesebaran ikan sidat A. bicolor bicolor. Ikan sidat A. marmorata terdapat pada perairan bagian utara yang tidak berbatasan dengan Samudra Hindia. Affandi (2017), menyatakan bahwa pesebaran ikan sidat A. marmorata di perairan Indonesia meliputi Sulawesi, Papua, Maluku, dan perairan bagian utara Nusa Tenggara. Kabupaten Lombok Utara termasuk ke dalam jalur pesebaran tersebut sehingga sangat memungkinkan terdapatnya ikan sidat berjenis $A$. marmorata pada kawasan perairannya.

Faktor lingkungan yang merupakan gambaran kualitas suatu kawasan perairan merupakan hal yang berpengaruh penting terhadap kelimpahan sumberdaya ikan, termasuk ikan sidat $A n$ guilla spp. Lucas and Baras (2001), menyatakan bahwa ikan sidat merupakan ikan yang melakukan migrasi pada setiap fase kehidupannya. Saat masih berada dalam fase glass eel, ikan sidat melakukan migrasi dari lingkungan perairan laut menuju lingkungan perairan estuari. Saat memasuki fase elver, ikan sidat akan bergerak memasuki kawasan perairan tawar dan akan terus bergerak hingga sampai bagian hulu sungai untuk hidup dan menetap sampai pada fase silver eel. Silver eel yang sudah matang gonad akan kembali melakukan migrasi ke perairan laut untuk melakukan reproduksi (Davey and Jellyman, 2005). Dou et al. (2008), menyatakan bahwa aktivitas migrasi tersebut dapat berlangsung karena 
Table 3 Identifikasi ikan sidat hasil tangkapan

\begin{tabular}{ccccccc}
\hline No & Lokasi penangkapan & Dorsal $(\mathrm{cm})$ & Anal $(\mathrm{cm})$ & Ruas tulang anodorsal & Morfometrik $(\%)$ & Warma \\
\hline 1 & Sungai Kapu & 22 & 17 & 15 & 17 & Corak bertotol \\
2 & Sungai Montongpal & 7 & 5 & 14 & 20 & Corak bertotol \\
3 & Sungai Sire & - & - & - & - & - \\
\hline
\end{tabular}

adanya rangsangan berupa nilai atau kadar tertentu pada faktor lingkungan (parameter fisikakimia perairan) di habitatnya.

Beberapa faktor lingkungan (parameter fisikakimia perairan) yang mempengaruhi aktivitas kehidupan serta kegiatan migrasi ikan sidat antara lain; suhu, pH, DO, salinitas, dan kekeruhan. Hasil pengamatan kualitas perairan pada kawasan perairan tempat pengamatan dapat dilihat pada Tabel 4.

Hasil pengamatan kualitas air pada beberapa lokasi pengambilan contoh ikan sidat menunjukkan bahwa kondisi lingkungan di lokasi tersebut masih berada pada kisaran nilai yang optimum untuk kehidupan dan pertumbuhan ikan sidat. Kim et al. (2006) yang didukung oleh Harrison et al. (2014) menyatakan bahwa nilai suhu lingkungan sangat berpengaruh terhadap terjadinya proses ruaya. Suhu lingkungan mempengaruhi aktivitas benih sidat terkait dengan gerakan berenang maupun meloncat. Usui menyatakan bahwa kisaran nilai suhu optimal yang dapat mendukung kehidupan ikan sidat adalah 21-31 ${ }^{\circ} \mathrm{C}$. Ritonga (2014) menyatakan bahwa nilai $\mathrm{pH}$ yang optimum untuk kehidupan ikan sidat adalah 6,0-8,0. Herianti (2005), menyatakan bahwa kadar oksigen terlarut yang baik bagi kehidupan ikan sidat adalah $>3,0 \mathrm{ppm}$.

Kecerahan perairan yang tinggi pada setiap kawasan sungai tempat pengambilan contoh mengindikasikan bahwa pada kawasan sungai tersebut belum terjadi peningkatan debit air akibat banjir dari daerah hulu sungai. Haryono and Wahyudewantoro (2017) menyatakan bahwa aktivitas banjir merupakan salah satu indikator penting dalam kegiatan migrasi ikan sidat. Intensitas debit air yang tinggi dari daerah hulu dapat menjadi pemicu ikan sidat untuk melakukan migrasi. Terlebih saat fase bulan gelap, maka secara alamiah ikan sidat akan menjadi lebih aktif dan lebih terpicu untuk melakukan migrasi. Dou et al. (2008) menyatakan bahwa ikan sidat cenderung lebih aktif pada malam hari (nokturnal). Pada saat terang, benih sidat lebih banyak berlindung den- gan sedikit makan dan sebaliknya akan meningkat pada saat gelap.

\section{SIMPULAN}

Kawasan perairan Lombok Utara, khususnya pada kawasan Sungai Montongpal, memiliki potensi sumberdaya ikan sidat jenis Anguilla marmorata.

\section{References}

Affandi, R. (2017). Strategi pemanfaatan sumberdaya ikan sid at, anguilla spp. di indonesia [strategy on utilization of eel (, anguilla sp.) resources in indonesia]. Jurnal Iktiologi Indonesia, 5(2):77-81.

Aoyama, J. (2009). Life history and evolution of migration in catadromous eels (genus anguilla).

Budiharjo, A. (2010). Migrasi Larva Sidat (Anguilla spp.) di Muara Sungai Progo. $\mathrm{PhD}$ thesis, Universitas Gadjah Mada.

Davey, A. J. and Jellyman, D. J. (2005). Sex determination in freshwater eels and management options for manipulation of sex. Reviews in fish biology and fisheries, 15(12):37-52.

Dou, S.-Z., Yamada, Y., Okamura, A., Shinoda, A., Tanaka, S., and Tsukamoto, K. (2008). Temperature influence on the spawning performance of artificiallymatured japanese eel, anguilla japonica, in captivity. Environmental biology of fishes, 82(2):151-164.

Fahmi, M. R. (2010). Phenotypic platisity kunci sukses adaptasi ikan migrasi: Studi kasus ikan sidat (anguilla sp.). In Prosiding Forum Inovasi Teknologi Akuakutur. Depok: Balai Riset Budidaya Ikan Hias.

Fahmi, M. R. (2015). Conservation genetic of tropical eel in indonesian waters based on 
Table 4 Pengukuran parameter fisika kimia perairan

\begin{tabular}{lcccccc}
\hline No & Lokasi & Suhu $\left({ }^{\circ} \mathrm{C}\right)$ & $\mathrm{pH}$ & DO $(\mathrm{ppm})$ & Salinitas $(\mathrm{ppt})$ & Kecerahan $(\%)$ \\
\hline 1 & Sungai Kapu & $20-28$ & $7.2-7.8$ & $4.5-6.5$ & 0 & 100 \\
2 & Sungai Montongpal & $20-27$ & $7.4-7.8$ & $4.3-5.4$ & 0 & 100 \\
3 & Sungai Sire & $22-29$ & $7.5-8.1$ & $4.0-5.7$ & 0 & 100 \\
\hline
\end{tabular}

population genetic study. In Prosiding Seminar Nasional Masyarakat Biodiversitas Indonesia, volume 1, pages 38-43.

FAO (2014). Globefish research programme, eel anguilla spp.: production and trade. Technical report, Food and Agriculture Organization.

Haraldstad, Ø., Vøllestad, L., and Jonsson, B. (1985). Descent of european silver eels, anguilla anguilla 1., in a norwegian watercourse. Journal of Fish Biology, 26(1):3741.

Harianto, E. (2014). Kinerja produksi ikan sidat (anguilla marmorata) ukuran 7 gram dengan kepadatan tinggi pada sistem resirkulasi melalui kajian fisiologis.

Harrison, A. J., Walker, A. M., Pinder, A. C., Briand, C., and Aprahamian, M. W. (2014). A review of glass eel migratory behaviour, sampling techniques and abundance estimates in estuaries: implications for assessing recruitment, local production and exploitation. Reviews in fish biology and fisheries, 24(4):967-983.

Haryono, H. and Wahyudewantoro, G. (2017). Pemetaan habitat ruaya benih ikan sidat (anguilla bicolor) dan potensinya di pantai selatan jawa. Omni-Akuatika, 12(3).

Herianti, I. (2005). Rekayasa lingkungan untuk memacu perkembangan ovarium ikan sidat (anguilla bicolor). Oseanologi dan Limnologi, 37:25-41.

Kim, W. S., Yoon, S. J., Kim, J. W., Lee, J. A., and Lee, T. W. (2006). Metabolic response under different salinity and temperature conditions for glass eel anguilla japonica. Marine Biology, 149(5):1209-1215.

KKP (2011). Panduan budidaya ikan sidat Anguilla spp. Kementerian Kelautan dan Perikanan.

Lucas, M. and Baras, E. (2001). Migration of Freshwater Fishes. Blackwell Science, 1 edition.

Matsui, I. (1982). Theory and practice of eel culture. AA. Balkema, Rotterdam.
Ndobe, S. (2010). Struktur ukuran glass eel ikan sidat (anguilla marmorata) di muara sungai palu, kota palu, sulawesi tengah. $\mathrm{Me}$ dia Litbang Sulteng, 3(2).

Ringuet, S., Muto, F., and Raymakers, C. (2002). Eels: their harvest and trade in europe and asia. TRAFFIC BULLETIN-CAMBRIDGE-TRAFFIC INTERNATIONAL-, 19(2):80-106.

Ritonga, T. P. T. (2014). Respons benih ikan sidat (anguilla bicolor bicolor) terhadap derajat keasaman (ph).

Rovara, O. (2007). Karakteristik reproduksi, upaya maskulinisasi dan pematangan gonad ikan sidat betina (anguilla bicolor bicolor) melalui penyuntikan ekstrak hipofisis.

Sugeha, H. Y., Suharti, S. R., Wouthuyzen, S., and Sumadhiharga, K. (2008). Biodiversity, distribution and abundance of the tropical anguillid eels in the indonesian waters. $M a$ rine Research in Indonesia, 33(2):129-138.

Suitha, M. I. and Suhaeri, A. (2008). Budidaya sidat.

Tesch, F. et al. (2003). The eel. The eel., (Ed. 3).

Usui, A. (1974). Eel Culture. Fishing News Books.

Watanabe, S., Aoyama, J., Nishida, M., and Tsukamoto, K. (2005). Evaluation of the population structure of anguilla bicolor bicolor using total number of vertebrae and the mtdna control region. Coastal Marine Science, 29(2):65-169. 
